P-ISSN: 0216-7484

E-ISSN: 2597-8926

\title{
PEMBERDAYAAN LANSIA MELALUI KREASI SENI
}

\author{
Indro Moerdisuroso ${ }^{1)}$, Ataswarin Oetopo ${ }^{2)}$, Yufiarti $^{3)}$ \\ Program Studi Pendidikan Seni Rupa, Fakultas Bahasa dan Seni, \\ Universitas Negeri Jakarta ${ }^{1)}$ 2) \\ Program Studi Psikologi Pendidikan, Fakultas Ilmu Pendidikan, \\ Universitas Negeri Jakarta ${ }^{3)}$ \\ Email: indro@unj.ac.id ${ }^{1)}$ warin_shamady@yahoo.com ${ }^{2)}$ yufiarti@yahoo.co.id ${ }^{3)}$
}

\begin{abstract}
Empowering the Elderly through Art Creation. Improving the quality of life of the Indonesian population affects the increasing number of elderly people. For this reason, the elderly need to improve their quality of life. One solution in dealing with this situation is to empower the elderly through visual arts activities. The purpose of this community service is to empower the elderly through activities in creating art using multimedia guideline. In this activity, the target was 30 elderly residents of the Panti Sosial Tresna Werdha Bhakti Mulia 2, Cengkareng, West Jakarta. This activity uses training methods based on multimedia guidelines. This activity is held for $2 \mathrm{x}$ meetings, each for 2 hours. The training process was guided by the entire community service team, accompanied by three students, and officers from the nursing home. The outputs are the guidance on creating art, and documentation of the activities. Participants showed an enthusiastic attitude in participating in training activities to create art with the topic of flora drawing. They showed a happy attitude towards the image produced. From the whole series of this activities, it was concluded that participants could understand well the training material in multimedia. The activity of drawing flora can arouse pleasure and be proud of producing a work for elderly participants. Multimedia as a learning media suitable for use for the elderly. Creative arts activities can improve the quality of life of the elderly.
\end{abstract}

Keywords: art creation, elderly, multimedia guideline

\begin{abstract}
Abstrak
Pemberdayaan Lansia Melalui Kreasi Seni. Tujuan kegiatan Pengabdian Kepada Masyarakat ini ialah untuk memberdayakan lansia melalui kegiatan berkarya seni rupa menggunakan panduan multimedia. Peningkatan kualitas hidup penduduk Indonesia berpengaruh pada meningkatnya jumlah lansia. Untuk itu lansia perlu ditingkatkan kualitas hidupnya. Salah satu solusi dalam menghadapi situasi ini adalah memberdayakan lansia melalui kegiatan seni rupa. Dalam kegiatan ini sasarannya ialah lansia warga Panti Sosial Tresna Werdha Bhakti Mulia 2, Cengkareng, Jakarta Barat berjumlah 30 orang. Kegiatan pengabdian ini menggunakan metode pelatihan berdasarkan panduan multimedia. Kegiatan ini dilaksanakan selama 2 x pertemuan, masing-masing selama 2 jam. Proses pelatihan dipandu seluruh tim PKM, didampingi tiga mahasiswa, dan petugas dari Panti Werdha. Hasil kegiatan berupa panduan berkreasi seni rupa, dan dokumentasi kegiatan berkreasi seni rupa. Peserta menunjukkan sikap antusias dalam mengikuti kegiatan pelatihan berkreasi seni dengan topik menggambar flora. Peserta menampakkan sikap senang terhadap gambar yang dihasilkan. Dari seluruh rangkaian kegiatan PKM disimpulkan bahwa peserta dapat memahami dengan baik materi dalam multimedia pelatihan yang berupa video dan buku panduan. Kegiatan kreasi seni rupa menggambar flora dapat membangkitkan rasa senang dan bangga menghasilkan suatu karya bagi peserta lansia. Multimedia sebagai media pembelajaran sesuai digunakan untuk lansia. Kegiatan kreasi seni rupa dapat meningkatkan kualitas hidup lansia.
\end{abstract}

Kata kunci: kreasi seni rupa, lansia, panduan multimedia. 
DOI: https://doi.org/10.21009/sarwahita.152.03

P-ISSN: 0216-7484

E-ISSN: 2597-8926

\section{PENDAHULUAN}

Predikat manusia lanjut usia (lansia) seperti tercantum dalam Undang Undang Nomor 13 Tahun 1998 tentang Kesejahteraan Lansia ialah seseorang yang berusia 60 tahun ke atas. Jumlah kelompok lansia ini di Indonesia memperlihatkan grafik yang terus meningkat. Statistik Penduduk Lanjut Usia terbitan Badan Pusat Statistik (2017, h. 3) menunjukkan tahun 1971 proporsi kelompok lansia sebesar 4,5\% dari total penduduk Indonesia, tahun $20007,2 \%$, dan $20158,5 \%$. BPS memprediksi proporsi kelompok lansia pada 2035 akan mencapai 15,8\% dari $100 \%$ penduduk Indonesia, sehingga diperlukan penyesuaian batas usia lansia menjadi 71,7 tahun ke atas. Meningkatnya Usia Harapan Hidup (life expectancy), dan keberhasilan program Keluarga Berencana yang dimulai tahun 1970-an merupakan faktor yang ditengarai sebagai penyebab meningkatnya jumlah lansia. Peningkatan tersebut perlu diimbangi dengan berbagai program pemberdayaan lansia dalam memasuki proses penuaan secara produktif dan memuaskan. Pada sisi layanan perlu ditingkatkan jangkauan dan kualitas pelayanan serta tanggung jawab masyarakat untuk memenuhi kebutuhan jasmani dan rohani lanjut usia.

Pelayanan kebutuhan penanggulangan permasalahan lanjut usia masih berkisar pada aspek kesehatan, ekonomi dan sosial. Kebutuhan dasar secara batin (immaterial needs, basic needs atau psychological needs) masih kurang tersentuh. Proses pelayanan seharusnya sesuai dengan karakteristik lanjut usia,

sehingga kebutuhan mereka secara psikologis terpenuhi. Pembinaan kualitas emosi, kepekaan sosial dan estetis lanjut usia diperlukan untuk pemenuhan diri dan berekspresi diri agar kehidupannya bahagia. Menurut Fisher (1999), kreativitas dalam kegiatan senirupa merupakan fasilitas kesuksesan lansia yang mendorong perkembangan keterampilan memecah-kan masalah, memotivasi, dan menerapkan tindakan kreatif dalam pengelolaan diri pada kehidupannya sehari-hari. Selain itu penelitian Wengler (2015, h. 59) menemukan bahwa kegiatan berkreasi seni menghasilkan pengalaman yang bermakna, menyenangkan, memberi energi, dan menghasilkan peningkatan kualitas hidup.

Saat ini pelayanan lansia yang dilaksanakan umumnya berkisar pada membantu orang lain dengan menanggapinya saja. Padahal menurut pendapat Robert Bulter dan Lewis, bahwa:

"mental health personnel can learn much about how to help older people by respecting and benefiting from what the elderly have to create by them. Old age can be a time of emotional and sensory awareness and enjoyment.

(Pelayanan kesejahteraan sosial seharusnya dapat lebih banyak belajar tentang bantuan bagi para lansia. Caranya dengan belajar menanggapi dan bertindak sesuai dengan kemampuan lansia untuk berkreasi sendiri. Lansia dapat sewaktu-waktu menyadari kemampuan diri dan emosinya, serta menikmatinya) 
DOI: https://doi.org/10.21009/sarwahita.152.03

P-ISSN: 0216-7484

E-ISSN: 2597-8926

Kegiatan yang dilakukan para lanjut usia idealnya dilakukan di dalam maupun di luar ruang, seperti menekuni kegemaran (hobby) keterampilan, kegiatan keagamaan, olah raga, menonton TV, dan berorganisasi. Kegiatan yang bervariasi ini menyebabkan para lanjut usia dapat menikmati masa tuanya dan tidak merasa bosan serta kesepian. Dalam kondisi ini kualitas hidup lansia akan lebih baik dari pada tinggal di rumah keluarga yang kesepian karena kesibukan masingmasing anggota keluarga. Selain itu, dengan melakukan kegiatan di waktu senggang mereka dapat tetap merasa mampu dan berarti bagi orang lain, khususnya teman-teman, keluarga, bahkan bagi masyarakat luas. Sebagaimana dinyatakan Febriyati dan Suyanto (2017, h. 210), lansia umumnya merasa bahagia ketika mampu mengisi waktu luang dengan kegiatan yang berguna.

Kegiatan berkesenirupaan dapat dijadikan pendekatan pelayanan dalam menciptakan suasana, situasi, dan kondisi yang akomodatif serta kondusif. Lanjut usia tetap dapat berperan serta mengembangkan dan mengaktualisasikan diri bahkan mandiri di masyarakat. Kegiatan berkesenirupaan dapat menjadi suatu pendekatan untuk kegiatan batin yang menyenangkan, bebas berekspresi, bahkan dapat meningkatkan produktivitas hasil karyanya sebagai tambahan pengha-silan.

Lansia telah mengalami roda kehidupan yang belum dialami generasi muda. Misalnya interesnya yang besar pada filsafat, agama, seni atau bidang

lainnya. Hal tersebut perlu diekspresikan dalam hidup dan akan bermakna baginya. Pelayanan yang baik bagi dirinya sendiri dapat diekspresikan melalui kegiatan seni rupa.

Berdasarkan kondisi situasi di atas maka permasalahan mitra dapat diidentifikasi sebagai berikut.

1. Penyediaan prasarana dan sarana di panti werdha diutamakan pada fasilitas akomodasi, sejenis penginapan atau asrama. Hal ini merupakan perangkat standar untuk memenuhi kebutuhan fisik lansia. Misalnya ketersediaan tempat tidur, kamar mandi, ruang makan, ruang bersama, dan halaman serta taman. Selain itu terdapat sarana penunjang yang bersifat hiburan pengisi waktu seperti misalnya televisi, di mana bagi aktivitas fisik dan psikis lansia cenderung bersifat statis.

2. Penyelenggaraan kegiatan seharihari di dalam panti werdha cenderung pada bantuan pemeliharaan dan perawatan fisik lansia. Kegiatan yang mengarah pada pengembangan aspek psikis cenderung diselenggarakan atas inisiatif warga lansia sendiri, terutama kegiatan keagamaan. Jenis kegiatannya relatif sangat terbatas, dan kurang bervariasi, sehingga menimbulkan kesan membosankan. Hari-hari di panti terasa sangat panjang dan monoton.

3. Kegiatan tambahan pernah diadakan oleh pihak dari luar panti, dan jenis kegiatan baru ini dapat menambah semangat hidup lansia 
DOI: https://doi.org/10.21009/sarwahita.152.03

P-ISSN: 0216-7484

E-ISSN: 2597-8926

di dalam panti, namun tidak sustainable. Penyebab utamanya ketiadaan tenaga pendamping dari pihak penyelenggara panti untuk konsisten mengelola dan membina kegiatan tersebut. Sementara itu dari pihak warga lansia belum memiliki keterampilan yang cukup memadai untuk berperan sebagai pengelola dan pembina kegiatan terkait.

Berdasarkan identifikasi permasalahan mitra tersebut, solusi yang diajukan kepada mitra ialah PKM melalui kegiatan berkreasi seni rupa. Kegiatan ini akan mengatasi permasalahan pemberdayaan lansia, dalam bentuk pelatihan berkreasi seni rupa menggunakan panduan multimedia. Jenis kegiatan PKM ini diharapkan menjadi aktivitas yang menyenangkan, sehingga dapat meningkatkan semangat dan kualitas hidup para lansia.

Kegiatan seni rupa bagi lansia tidak menekankan pada keindahan karya yang dihasilkan, tetapi lebih pada menumbuhkan rasa senang, percaya diri (self confidence) dan rasa mandiri (self dependent). Pada akhirnya secara perlahan-lahan kegiatan ini memberi-kan rasa menggembirakan, kepuasan, dan kebahagiaan. Ekspresi dalam kegiatan seni rupa pada lansia merupakan refleksi diri yang dibutuhkan sepanjang hayat. Nilai kreativitas tidak berhubungan dengan kemunduran usia. Banyak orang menjadi kreatif untuk pertama kalinya pada usia lanjut. Lebih nyata lagi dalam masalah sosial keingintahuan dan kemampuan membuat kejutan merupakan kualitas adaptif yang

menyolok. Fungsi seni pun tidak berhenti hanya sampai pada melatih kelenturan motorik saja, melainkan lebih kepada pemenuhan kebutuhan ekspresi yang memberikan pengalaman artistik, membina kehalusan budi, ketekunan, kesabaran, keterbukaan, kerjasama, dan memberi peluang bagi pencurahan ketegangan jiwa. Adapun luaran yang dihasilkan dari kegiatan PKM ini ialah video panduan kegiatan kreasi seni rupa bagi lansia, dan dokumentasi kegiatan pelatihan berkreasi seni bagi lansia.

\section{METODE PELAKSANAAN}

\section{A. Tahapan Kegiatan}

Pemberdayaan lansia dilakukan secara holistik sebagai berikut:

a. Mendata jumlah lansia di lokasi mitra yang bersedia dilatih kegiatan kreasi seni rupa, dengan jumlah 30 orang

b. Mendisain panduan kreasi seni rupa bagi lansia dalam format multimedia

c. Merancang program pelatihan

d. Melaksanakan kegiatan pelatihan berdasarkan panduan

e. Evaluasi pelaksanaan kegiatan pelatihan

\section{B. Metode Pelaksanaan Pelatihan}

Penyusunan metode pelaksanaan didasarkan pada dua prinsip dasar yaitu: 1) belajar adalah kegiatan yang dialami dan menyenangkan yang terus terjadi sepanjang hidup, 2) kesulitan belajar adalah ketidakmampuan mengatasi stres dan keraguan dalam menghadapi suatu tugas yang baru. Untuk itu disusun langkah-langkah pelaksanaan pelatihan sebagai berikut: 
DOI: https://doi.org/10.21009/sarwahita.152.03

P-ISSN: 0216-7484

E-ISSN: 2597-8926

a. Pembekalan kepada peserta pelatihan, utamanya untuk memotivasi semangat dalam melaksanakan kegiatan seni rupa, yaitu menggambar flora, tidak mementingkan keindahan, tetapi kespontanan, sehingga tidak perlu kuatir hasilnya tidak bagus.

b. Pendampingan dalam mempelajari panduan multimedia, yang menggambarkan tahap-tahap dalam membuat lukisan

c. Pendampingan dalam mengawali proses pelaksanaan menggambar, dengan cara membimbing cara pemakaian bahan menggambar

d. Supervisi dalam proses akhir kegiatan menggambar, dengan cara memotivasi hasilnya cenderung sesuai dengan target yang diharapkan.

e. Evaluasi hasil karya, dengan cara menunjukkan kelebihan dan kekurangan, khususnya dalam hal teknik penggunaan pewarna krayon.

\section{Evaluasi Pelaksanaan Program dan Keberlanjutan Program}

Pelaksanaan PKM ini akan dievaluasi melalui instrumen wawan-cara yang diberikan kepada lansia peserta latihan setelah kegiatan selesai dilaksanakan. Daftar pertanyaannya sebagai berikut:

a. Apakah merasa bisa mengungkapkan ekspresinya?

b. Apakah merasa masih mampu menghasilkan sesuatu?

c. Apakah dirasakan ada pengaruh kelenturan motorik halus?

d. Apakah merasa senang dengan karya yang dihasilkannya?

e. Apakah ingin mengikuti lagi kegiatan berkreasi seni rupa?

Seluruh rangkaian pelaksanaan pelatihan tersebut disesuaikan dengan jadwal kegiatan yang telah direncanakan, yaitu kegiatan pelatihan dilaksanakan sebanyak dua kali pertemuan. Pertemuan pertama pada tanggal 18 September 2018, kedua tanggal 21 September 2018 pukul 10.00 - 12.00. Kedua pertemuan berlangsung di aula Panti Tresna Werdha Budi Mulia 2, Jalan Cenderawasih 10, Cengkareng, Jakarta Barat.

\section{HASIL DAN PEMBAHASAN}

Program PKM ini telah dilaksanakan sesuai perencanaan, yang diawali dengan pengurusan surat izin dan persetujuan dari Mitra yaitu Panti Sosial Werdha (PSW) Budi Mulia 2, Cengkareng, Jakarta Barat. Dalam program ini diutamakan membangun jejaring antara Panti Werdha dengan Tim PKM UNJ, sehingga para lanjut usia (Lansia) diharapkan dapat berapresiasi dan berkreasi seni rupa dengan menggunakan media ekspresi yang mudah diperoleh dan harga terjangkau.

\section{A. Kreasi Seni Rupa dalam Program PKM}

Pembelajaran berkreasi seni rupa dalam program PKM ini berupa pelatihan Menggambar Dasar Flora pada kertas gambar dengan krayon. Peserta pelatihan berjumlah 30 orang yang keseluruhannya merupakan warga binaan Panti Sosial Werdha Budi Mulia 2. Media pembelajaran yang digunakan berupa multimedia yang terdiri dari video 
DOI: https://doi.org/10.21009/sarwahita.152.03

P-ISSN: 0216-7484

E-ISSN: 2597-8926

tutorial dan lembar Panduan Kreasi Seni Rupa Untuk Lansia, yang berisi tahapan penerapan menggambar flora pada media kertas gambar menggunakan krayon dan spidol.

Narasumber dan instruktur dalam pelatihan ini ialah ketua PKM, dua anggota pelaksana PKM, dan tiga mahasiswa Program Studi Seni Rupa, FBS-UNJ. Para Pembina (care giver) dan pengurus Panti Sosial Werdha Budi Mulia 2 (PSW-BM2) turut berparti-sipasi selama pelaksanaan pelatihan ini.

\section{B. Tahapan Pelaksanaan Pelatihan}

Kegiatan dilaksanakan selama dua kali pertemuan, masing-masing selama dua jam, yaitu dari pukul 10.00-12.00. Waktu tersebut disesuaikan dengan kemampuan seusia lansia dan kegiatan rutin keseharian mereka di Panti. Pertemuan pertama dilaksanakan pada hari Selasa 18 September 2018 dan pertemuan kedua pada hari Jumat 21 September 2018. Setiap pertemuan diawali dengan berdoa, bernyanyi Hymne Lansia, menayangkan video tutorial, melaksanakan kegiatan menggambar, dan bersama-sama mengevaluasi hasil karya serta pelaksanaan pelatihan. Berdasarkan pengamatan terhadap sikap dan perilaku dalam tahap penayangan video panduan menggambar florsa, peserta umumnya menyimak tayangan tersebut. Selanjutnya ketika memasuki tahap menggambar, peserta terlihat menjalani tahapan menggambar sebagaimana urutan menggambar dalam tayangan video.

Selama berlangsungnya proses menggambar, sebagian besar peserta

menunjukkan ekspresi wajah bersungguh-sungguh. Hal ini mengindikasikan peserta cenderung menyukai kegiatan ini. Adapun terhadap gambar flora yang dihasilkan secara umum memperlihatkan kualitas teknis yang relatif rendah. Kemungkinan penyebabnya antara lain mayoritas peserta sangat jarang, bahkan mungkin belum pernah malkukan kegiatan menggambar menggunakan media krayon. Kemungkinan ini bisa terjadi karena latar belakang ekonomi bawah sehingga tidak memiliki pengalaman memakai media krayon. Adapun untuk hasil menggambar yang menunjukkan kualitas teknis baik, yang jumlahnya hanya dua karya, ternyata dihasilkan oleh kakak beradik yang berlatar belakang ekonomi menengah. Menurut pengakuan yang bersangkutan bahkan mengenyam pendidikan tinggi namun tidak selesai.

\section{Evaluasi Pelaksanaan Program dan Keberlanjutan Program}

Pelaksanaan PKM dievaluasi melalui wawancara yang diberikan kepada peserta latihan pada saat pelaksanaan dan setelah kegiatan selesai. Hasil evaluasi pelaksanaan dan keberlanjutan program pelatihan ini, secara umum sangat dirasakan positif oleh para lansia. Mereka merasa dapat dengan santai mengungkapkan ekspresinya melalui kegiatan menggambar dasar bertema flora. Kesenangan para lansia terpancar secara emosional setelah merasa mampu menyelesaikan suatu karya. Hasil evaluasi terkait psikologi peserta ini sejalan dengan hasil penelitian tentang kegiatan berkreasi seni rupa celup ikat bagi lansia yang berperan positif dalam 
DOI: https://doi.org/10.21009/sarwahita.152.03

P-ISSN: 0216-7484

E-ISSN: 2597-8926

peningkatan kualitas hidup lansia. Para lansia menjadi terampil, mampu menghasilkan kreasi yang bermanfaat, baik untuk diri sendiri maupun orang lain, sehingga membangun harapan bahwa hidupnya masih berguna dan bermakna (Oetopo, 2013).

\section{PENUTUP}

\section{A. Kesimpulan}

Pelaksanaan seluruh rangkaian kegiatan PKM Pelatihan Berkreasi Seni Rupa bagi Lansia di Panti Werdha Budi Mulia 2 menghasilkan kesimpulan sebagai berikut:

1. Peserta menunjukkan sikap antusias dalam mengikuti kegiatan pelatihan berkreasi seni dengan topik menggambar flora

2. Peserta menampakkan sikap senang terhadap gambar yang dihasilkan.

3. Peserta dapat memahami dengan baik materi yang terdapat dalam multimedia pelatihan berupa video dan buku panduan.

4. Multimedia sebagai media pembelajaran sesuai digunakan untuk lansia.

5. Kegiatan kreasi seni rupa menggambar flora dapat membangkitkan rasa senang dan bangga menghasilkan suatu karya bagi peserta lansia.

6. Kegiatan kreasi seni rupa dapat meningkatkan kualitas hidup lansia.

\section{B. Saran}

Setelah seluruh rangkaian proses pelatihan berkreasi seni rupa bagi lansia selesai dilaksanakan, dapat disampaikan saran sebagai berikut:

1. Bagi Tim PKM dapat mengembangkan pelatihan berkreasi seni rupa dengan topik yang sama dengan pendalaman tertentu, atau topik selain menggambar flora.

2. Bagi institusi Panti Werdha agar menyediakan sarana dan mengelola kegiatan berkreasi seni rupa dalam berbagai kemungkinan topik seni rupa

\section{DAFTAR PUSTAKA}

Ahmadi, Abu. 1991. Sosiologi Pendidikan. Jakarta: PT. Rineka Cipta.

Febriyati, Suyanto. 2017. Pemberdayaan Lansia melalui Usaha Ekonomi Produktif oleh Bina Keluarga Lansia (BKL) Mugi Waras di Kabupaten Sleman. Jurnal Pemberdayaan Masyarakat, Vol. 1 No. 1, (2017): 209-226.

Grasha, Anthony F, Daniel S, \& Kirschenbaum. 1980. Psychology of Adjusment and Competence An Approach, Cambridge: Winthrop Publishers, Inc.

Harton, Paul dan Chester L, Hunt. 1992. Sosiologi, Jilid II, Jakarta: Erlangga.

Maylasari, Ika, Sulistyowati, Ramadani, \& Anissa. 2017. Statistik Penduduk Lanjut Usia 2017. Dwi Susilo, Harahap \& Sinang (Eds.). Jakarta: Badan Pusat Statistik.

Oetopo, Ataswarin. 2013. Tie Dye Creation at The Study of Fine Arts in Life Quality Improvement of Elders, Case Study in Sasana Tresna Werdha, Yayasan Karya Bakti Ria Pembangunan, Jakarta. Proceeding. 
DOI: https://doi.org/10.21009/sarwahita.152.03

P-ISSN: 0216-7484

E-ISSN: 2597-8926

Internasional Art Educational 2013, Universitas Negeri Sebelas Maret, Surakarta.

Tim Penulis. 2000. National Plan of Action for Elderly Welfare. Jakarta: State Ministry of Transmigration and Population Republik Indonesia.

Wengler, Therese A. (2015). The Importance of a Creative Arts Program for Senior Housing Residents. Thesis. Retrieved from Sophia, the St. Catherine University repository website: https://sophia.stkate.edu/ma_osot/8 